\title{
Şaraplık üzüm çeşitlerinde tane ve salkım gelişiminin zamana bağlı olarak değişimi*
}

\author{
Adem YAĞCI $\left(\mathbb{D}^{1}\right.$, Abdurrahim BOZKURT ${ }^{(D 2}$ \\ 1Tokat Gaziosmanpaşa Üniversitesi Ziraat Fakültesi Bahçe Bitkileri Bölümü, Tokat \\ ${ }^{2}$ Erzincan Bahçe Kültürleri Araştırma Enstitüsü Müdürlüğü, Erzincan
}

*Bu çalışma; “Kırşehir Koşullarında Yetiştirilen Bazı Şaraplık Üzüm Çeşitlerinin Verim ve Bazı Kalite Özelliklerinin Belirlenmesi” isimli Yüksek Lisans çalıșmasının bir kısmıdır.

Alınış tarihi: 7 Mayıs 2020, Kabul tarihi: 3 Eylül 2020

Sorumlu yazar: Adem YAĞCI, e-posta: adem.yagci@gop.edu.tr

Öz

$\mathrm{Bu}$ çalışma 2017 ve 2018 yılları arasında Kavaklıdere Şarapları A.Ş'ye ait Kırşehir İlinin Toklumen bağlarında yapılmıştır. Bu çalışma ile Kırşehir koşullarında Kalecik Karası, Öküzgözü ve Boğazkere çeşitlerinin tane ve salkımlarında zamana bağlı olarak fiziksel ve kimyasal değişimleri belirlemek amaçlanmıştır. Çalışma yapılan bağlar 2006 ve 2011 yılları arasında kurulmuştur. Hasat esnasında yıllara göre SÇKM değeri sırasıyla Boğazkere çeşidinde \% 20.4 - 21.1, Kalecik Karası çeşidinde \% 24.3 - 23.7 ve Öküzgözü çeșidinde \% 22.2 - 21.4; toplam asitlik miktarı Boğazkere çeşidinde 7.11-4.84 g/l, Kalecik Karası çeşidinde 6.08-7.60 g/l, Öküzgözü çeșidinde 5.55-5.70 g/l olarak belirlenmiștir. Çeșitler arasında kabukta flavonoid içerikleri bakımından her iki yılda da en yüksek değerler Öküzgözü çeşidinde tespit edilmiştir (134-111 mg QUE/g). Üzüm tanelerinde bulunan fenolik bileşik, flavonoid ve antosiyanin değerleri çeşit ve yıl bazında farklılık göstermiştir.

Anahtar kelimeler: Vitis vinifera L., fizikokimyasal içerik, Spektrofotometrik yöntemler, Kırşehir

\section{Changing of cluster and berry characteristics depending on time in wine grapes cultivars}

\footnotetext{
Abstract

This study was carried out between 2017 and 2018 in the Toklumen region of Kırşehir Province, which belongs to Kavaklidere Winery. With this study, it was aimed to determine the physical and chemical changes in the berry and clusters of Kalecik Karası,
}

Öküzgözü and Boğazkere varieties under Kırşehir conditions depending on the time. The vineyards conducted in the study were established between 2006 and 2011. In the vintage season, SÇKM value of Boğazkere, Kalecik Karası and Öküzgözü are 20.4 $21.1 \%, 24.3-23.7 \%$, and $22.2-21.4 \%$, respectively. The total acidity was determined as 7.11-4.84 g / L in Boğazkere cultivar, 6.08-7.60 g / L in Kalecik Karası cultivar and 5.55-5.70 g / L in Öküzgözü cultivar. The highest values in the skin in terms of flavonoid contents were determined in the Öküzgözü cultivar in both years (134-111 mg QUE / g). It was observed that phenolic compound, flavonoid and anthocyanin contents in grape berries varied by cultivars and years.

Key words: Vitis vinifera L., Physicochemical content, spectrophotometric methods, Kirşehir

\section{Giriş}

Üzüm taneleri, çiçek salkımında bulunan çiçek tomurcuklarının tozlanma ve döllenme olaylarını takiben meydana gelir. Üzüm tanelerinin bir araya gelerek oluşturdukları yapı salkım olarak ifade edilmektedir (Çelik ve ark.,1998; Çelik, 2011). Salkım ve tane özellikleri (şekil, renk, en, boy) üzüm çeşitlerine göre değişmektedir. Ayrıca salkım ve tane özellikleri; gözlerin yıllık dallar üzerindeki yeri, toprak, yağıșlar, gübreleme, budama, kullanılan pestisit, hormon ve büyüme düzenleyiciler, çiçeklenme ve tane olușum devresindeki hava durumundan etkilenmekte ve bu etki yıldan ylla değişkenlik gösterebilmektedir (Çelik ve ark., 1998; Çelik, 2011; Kamiloğlu ve Üstün, 2014). Olgunluğa 
doğru tanelerde fiziksel ve kimyasal değişimler olmaktadır.

Üzüm șırasında bulunan suda çözünebilir kuru madde miktarı (SÇKM) tanenin olgunlaşma süresince artmaktadır (Pirie ve Mulnis, 1980; Deryaoğlu ve Canbaş, 2003). SÇKM birikimine bağlı olarak artan tane ağırlığı ile beraber tane eti sertliğinde yumuşama meydana gelmektedir (Aydın, 2015). Şaraba işlenecek üzümlerde SÇKM değeri üzümlerin rengine göre değișebilmektedir. SÇKM miktarı siyah şaraplık üzüm çeșitlerinde \% 21-24 (Amerine ve ark.,1980; Deryaoğlu ve Canbaş, 2004), kırmızı şaraplık üzüm çeşitlerinde \% 20.0-23.5 (Winkler ve ark.,1974; Uluocak, 2010), beyaz şaraplık üzüm çeşitlerinde ise \% 19.0-23.0 arasında (Cooke ve Berg,1983; Kamiloğlu ve Üstün, 2014) olması gerektiği belirtilmektedir.

Üzümlerde organik asitler içerisinde en fazla tartarik asit (şarap asidi) bulunmaktadır. Üzümlerde bulunan asit miktarı tanenin 1'nci ve 2'nci gelişime safhalarında artar, ben düşme başlangıcında (3'ncü safha) maksimuma ulașmakta ve ben düșme döneminden sonra hızlı bir șekilde azalmaya başlamaktadır (Ağaoğlu, 2002). Bu azalma; olgunlaşma süresince tanede meydana gelen reaksiyonların bir sonucu olarak gerçekleşmektedir (Ağaoğlu, 2002; Deryaoğlu ve Canbaş, 2003, 2004; Cangi ve ark.,2011; Keskin ve ark. 2013).

Şıranın pH değeri üzümlerin sahip olduğu renk ve tat bileșenlerini de belirlemekte ve ben düșme'den hasat dönemine kadar sürekli bir artış göstermektedir (Ağaoğlu, 2002; Cangi ve ark., 2011; Yüksel, 2014; Şan, 2016). Olgunlaşmaya paralel olarak pH'daki bu artışla (rakamsal olarak) birlikte üzümde istenmeyen tatların da baskılandığı bildirilmektedir (Winkler ve ark.,1974; Ağaoğlu, 2002). Özellikle şaraplık üzümlerde pH birçok araştırıcı tarafından önemsenmektedir.

Fenolik bileşikler doğal bir antioksidan kaynağı olup (Tomera, 1999) erken yaşlanma ve kanser gibi hastalıları tetikleyen serbest radikalleri yakalamakta ve oksidatif hasara neden olan substratın oksidasyonunu büyük ölçüde geciktirmektedir (Ateş, 2015; Karadoğan ve ark., 2018; Keskin ve ark., 2018). Fenolik bileşikler üzüme ve üzüm ürünlerine (meyve suyu, şarap) renk, koku ve tat sağlayan ve aynı zamanda şarabın kalitesini belirleyen en önemli parametrelerdir (Söylemezoğlu, 2003; Bozdoğan ve ark., 2005; Kelebek 2009; Keskin ve ark. 2018; Uzun ve ark., 2019a; Uzun ve ark., 2019b). Sö konusu bu maddeler üzüm kabuğunda (\% 33.3), meyve etinde
(\% 4.1) ve çekirdekte (\% 62.6) bulunmaktadır (Ough ve Amerine 1988; Bozdoğan ve ark., 2005).

Flavonoidler, antioksidan özelliklerinin yanı sıra, meyve ve çiçeklerde renk oluşturan ve ekolojik faktörlerin sebep olduğu stres etmenlerine karşı bitkileri koruyan maddelerdir (Ateş, 2015). Flavonoller daha çok üzüm kabuğunda bulunmakla beraber çok az miktarda da çekirdek ve tane etinde bulunmaktadır. Bu pigmentler; siyah ve beyaz üzümlerin renklenmesinde etkilidirler (Moskowitz ve Hrazdina, 1981; Kunter ve ark., 2013).

Antosiyaninler yağda (Karoten) ve suda çözünebilen maddelerdir (Dıblan, 2013; Kunter ve ark., 2013). Bu maddeler genellikle üzüm kabuğunda bulunmaktadır. Ben düșme döneminden itibaren bu maddelerin miktarları artmaktadır (Ağaoğlu,2002; Uzun ve ark., 2019a; Uzun ve ark., 2019b). Olgunlaşma döneminde maksimum düzeye ulaşarak, üzüm çeşidinin kendine has rengini sağlarlar (Kunter ve ark., 2013) ve renkli üzüm çeşitlerinde daha fazla bulunmaktadırlar (Polat, 2016).

Bu çalıșmada Boğazkere, Kalecik Karası ve Öküzgözü üzüm çeşitlerinin zamana bağlı olarak salkım ve tanede meydana gelen fiziksel ve kimyasal değişimlerin belirlenmesi ve çeşitlerin birbirleri ile karşılaştırılması amaçlanmıştır.

\section{Materyal ve Yöntem}

Çalışma 2017 ve 2018 yıllarında Kırşehir ilinde iki yıl süre ile üretici koşullarımnda $\left(39^{\circ} 10^{1} 03.00^{11} \mathrm{~N}\right.$, $33^{\circ} 43^{1} 26.00^{\prime \prime}$ E), Boğazkere, Kalecik Karası ve Öküzgözü üzüm çeșitlerinde yapılmıștır. Çeșitlere ait omcalar 1103 Paulsen anacı üzerinde ve 11-12 yaşlarındadır. Bağda dikim sıklığı 2.0 m x 1.0 m ve terbiye sistemi duvardır. Bağlarda toprak işleme, kış budaması, ilaçlama, yeşil budama, sulama, gübreleme ve hasat gibi işlemler standart olarak yapılmıştır. Çalışmanın yapıldığı bağ toprakları killi tınlı yapıda, organik maddece fakir (\%0.57-1.39) ve hafif kireçlidir (\%7-10). Çalışmaya konu olan üzüm çeşitleri Türkiye'nin en önemli renkli şaraplık üzüm çeşitleridir. Çeşitlerin uluslararası Vitis numarası Boğazkere 1505 (Şekil 1), Kalecik Karası 5936 (Şekil 2) ve Öküzgözü 8708'dir (Şekil 3).

\section{Yöntem}

Üzüm çeşitlerinde tanelere ben düşme döneminden itibaren salkım örnekleri alınmaya başlanmıştır. Soğuk zincirde laboratuvarına getirildikten sonra aşağıdaki fiziksel ve kimyasal analizler gerçekleştirilmiştir. 


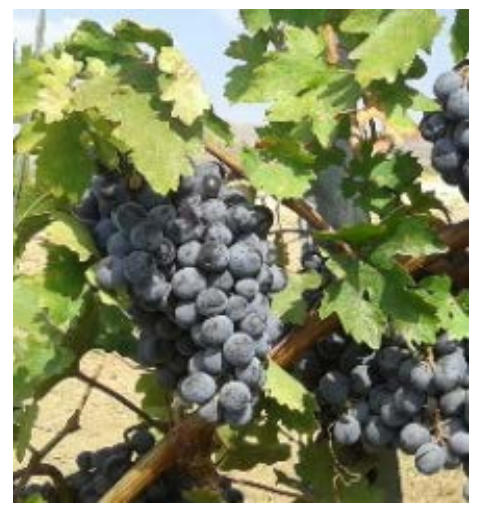

Şekil 1. Boğazkere

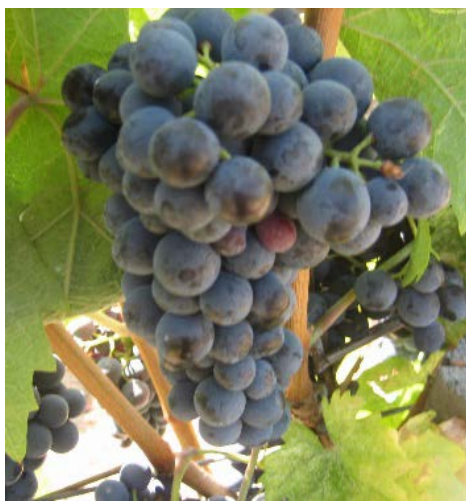

Șekil 2. Kalecik karası

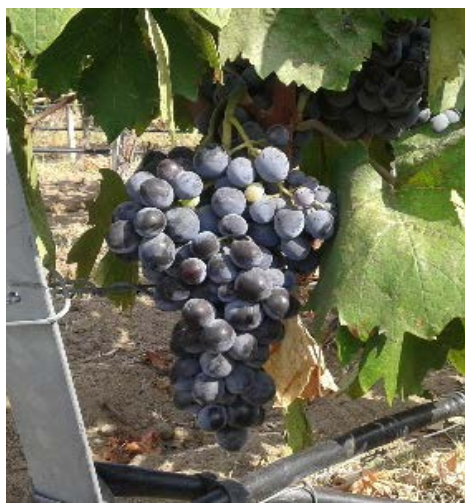

Şekil 3. Öküzgözü

\section{Fiziksel analizler}

Salkım ağırlığı ve tane ağırlığı (g) tartılarak (Precisa BJ 1200C), salkım eni ve salkım boyu (cm) cetvel ile, tane eni ve boyu (mm) kumpas ile, tane eti sertliği (Newton) 1.54 mm'lik delici uca sahip sertlik ölçerle (PCE, SLJ-B) ölçülmüştür.

\section{Kimyasal analizler}

Suda Çözünebilir Kuru Madde (SÇKM-\%) miktarı refraktometre ile (Atago Master-93H); titre edilebilir asitlik miktarı (g/l) Cemeroğlu (1992)'na göre; şıranın pH'sı ise pH metre ile (WTW Inolab pH 7310) belirlenmiştir. Tanenin toplam fenolik, toplam flavonoid ve toplam antosiyanin içeriklerinin belirlenmesinde; Örnek hazırlığı Bino ve ark. (2005)'na göre yapıldı. Toplam fenolik miktarı (mg GAE/100gr kuru madde) Velioğlu ve ark. (1998)'na göre, toplam flavonoid miktarı (mg QE-CE/100 gr) Zhishen ve ark.(1999)'na göre ve toplam antosiyanin miktarı (mg/g) Di Stefano ve Cravero (1991)'ya göre belirlenmiştir.

\section{Etkili sıcaklık toplamı (EST)}

Çalışmanın yapıldı̆̆ı yerde bulunan Meteoroloji istasyonundan günlük ortalama sıcaklıklar $\left({ }^{\circ} \mathrm{C}\right)$ alınmış ve aşağıdaki formüle göre EST değerleri hesaplanmıştır.

$\mathrm{EST}=\Sigma(\mathrm{T}-\mathrm{Te})$

EST = Etkili sıcaklık toplamı, $\mathrm{T}=$ Günlük ortalama sıcaklık, Te: Eşik sıcaklığı ( ${ }^{\circ} 10 \mathrm{C}$ )

\section{İstatistiksel analiz}

Veriler; tesadüf blokları deneme deseninde, 3 tekerrürlü ve her tekerrürde 18 omca olacak șekilde varyans analizine tabii tutulmuştur. Ortalamaların karşılaştırılmasında LSD $(0.05)$ testinden yararlanılmış ve her haftanın verileri ayrı ayrı analiz edilmiştir. Çeşitlerin farklı zamanlarda olgunlaşmasından dolayı hasat zamanlarında elde edilen veriler tekrar istatiski analize tabii tutulmuştur.

\section{Bulgular ve Tartışma}

2017 ve 2018 yılında Boğazkere, Kalecik Karası ve Öküzgözü çeşitlerinin salkım ağırlı̆̆ı, salkım eni, salkım boyu, SÇKM, pH ve asitlik değerleri Çizelge 1 ve 2 'de verilmiştir.

2017 yılında 12 Eylül, 2018 yılında ise 14 ve 28 Eylül tarihlerinde salkım ağırlığına ait veriler arasındaki farklılıklar istatistiksel anlamda önemsiz bulunmuştur. Salkım enleri arasındaki farklılıklar, çalışmanın ilk yılında istatistiki olarak önemsiz olurken, ikinci yllda hasat dönemine doğru önemli bulunmuştur. 2017 yılında ben düşme'den hasada kadar en yüksek salkım ağırlıkları: Öküzgözü > Kalecik Karası > Boğazkere şeklinde sıralanmıştır. 2018 yılında salkım ağırlığ bakımından yine Öküzgözü çeşidi ilk sırada yer alırken, Kalecik Karası ve Boğazkere çeşitleri dönemsel olarak değişkenlik göstermiştir. Hasat döneminde salkım ağırlı̆̆ı değerleri yıllara göre sırasıyla Öküzgözü çeşidinde 350.2 g - 424.2 g, Kalecik Karası çeşidinde 236.6 g $198.2 \mathrm{~g}$ ve Boğazkere çeşidinde $182.6 \mathrm{~g}-375.0 \mathrm{~g}$ olarak meydana gelmiştir (Çizelge 1 ve Çizelge 2).

Çeşitlerin SÇKM miktarları ben düşme döneminde düşük iken (\%5.4-14.1); 6-8 haftalık bir zaman diliminde artarak devam etmiştir. Her iki yılda da hasat döneminde elde edilen SÇKM değeri çeşitlere göre istatisitiki olarak önemli bulunmuştur. Hasat esnasında yıllara göre (2017-2018) SÇKM değeri sırasıyla Boğazkere'de: \% 20.4 - 21.1, Kalecik Karası'nda: \% 24.3 - 23.7 ve Öküzgözü'nde: \% 22.2 21.4 değerlerini almıştır (Çizelge 1 ve Çizelge 2). Üzümlerde SÇKM değeri: çeşit, yll (Ribereau Gayon, 2000; Deryaoğlu ve Canbaș, 2004), yılık yağıș miktarı ve etkili sıcaklık toplamı (Bekar ve Bayram, 2016), olgunluk periyodu, toprak yapısı, bağın 
bulunduğu yön (Borazan, 2008) ve anaçlar (Çelik, 1996; Ağaoğlu, 2002; Çelik, 2011) gibi bir çok faktör tarafından etkilenebilmektedir. $\mathrm{Bu}$ çalışmada; Öküzgözü, Boğazkere, ve Kalecik Karası üzüm çeşitlerine ait 2017 yılı SÇKM değerleri; Kök ve Çelik
(2003), Çelik (2012), Şan (2016) ve Bekar (2017)'ın bulgularından daha yüksektir. 2018 yılı SÇKM değerleri ise yukarıda verilen literatürle benzerlik göstermektedir.

Çizelge 1. Çeşitlerin 2017 yılı salkım ve şıra özellikleri

\begin{tabular}{|c|c|c|c|c|c|c|c|}
\hline \multirow{2}{*}{$\begin{array}{l}\text { Örnek alma } \\
\text { tarihi }\end{array}$} & \multicolumn{4}{|c|}{ Salkım } & \multirow[b]{2}{*}{ SÇKM (\%) } & \multirow[b]{2}{*}{$\mathrm{pH}$} & \multirow[b]{2}{*}{ Asit (g/l) } \\
\hline & Çeşit & $\begin{array}{l}\text { Salkım ağırlığı } \\
\text { (g) }\end{array}$ & $\operatorname{En}(\mathrm{cm})$ & Boy $(\mathrm{cm})$ & & & \\
\hline \multirow{3}{*}{$\begin{array}{l}15 \text { Ağustos } \\
2017\end{array}$} & Boğazkere & $51.2 \mathrm{~b}$ & 9.4 & $13.5 \mathrm{~b}$ & $5.4 \mathrm{c}$ & 2.83 & $38.5 \mathrm{a}$ \\
\hline & Kalecik Karası & $121.8 \mathrm{a}$ & 8.9 & $15.5 \mathrm{ab}$ & $14.1 \mathrm{a}$ & 2.84 & $15.49 \mathrm{~b}$ \\
\hline & Öküzgözü & $152.7 \mathrm{a}$ & 9.1 & $17.9 \mathrm{a}$ & $9.1 \mathrm{~b}$ & 2.70 & $24.36 \mathrm{~b}$ \\
\hline $\operatorname{LSD}_{(0.05)}$ & & 42.9 & ÖD & 3.2 & 2.6 & 0.00 & 11.83 \\
\hline \multirow{3}{*}{$\begin{array}{l}22 \text { Ağustos } \\
2017\end{array}$} & Boğazkere* & $71.9 \mathrm{~b}$ & 9.6 & $14.7 \mathrm{~b}$ & $7.0 \mathrm{c}$ & 2.87 & $35.26 \mathrm{a}$ \\
\hline & Kalecik Karası & $151.2 \mathrm{a}$ & 9.8 & $16.0 \mathrm{~b}$ & $17.1 \mathrm{a}$ & 3.08 & $13.2 \mathrm{~b}$ \\
\hline & Öküzgözü & $165.9 \mathrm{a}$ & 9.5 & $18.5 \mathrm{a}$ & $11.7 \mathrm{~b}$ & 3.00 & $16.44 \mathrm{~b}$ \\
\hline $\operatorname{LSD}_{(0.05)}$ & & 23.3 & ÖD & 1.6 & 1.3 & ÖD & 6.54 \\
\hline \multirow{3}{*}{$\begin{array}{l}29 \text { Ağustos } \\
2017\end{array}$} & Boğazkere & $110.5 \mathrm{~b}$ & 10.3 & 15.0 & $11.2 \mathrm{c}$ & 3.04 & $22.00 \mathrm{a}$ \\
\hline & Kalecik Karası & $181.6 \mathrm{a}$ & 9.9 & 16.5 & $19.9 \mathrm{a}$ & 3.11 & $9.23 \mathrm{~b}$ \\
\hline & Öküzgözü & $193.3 \mathrm{a}$ & 10.3 & 17.9 & $13.8 \mathrm{~b}$ & 3.05 & $11.12 \mathrm{~b}$ \\
\hline $\operatorname{LSD}_{(0.05)}$ & & 43.5 & ÖD & ÖD & 2.0 & ÖD & 2.71 \\
\hline \multirow{3}{*}{05 Eylül 2017} & Boğazkere & $164.5 \mathrm{~b}$ & 10.7 & 16.0 & $14.5 \mathrm{~b}$ & 3.09 & $17.84 \mathrm{a}$ \\
\hline & Kalecik Karası & $200.3 \mathrm{ab}$ & 10.0 & 16.6 & $21.3 \mathrm{a}$ & 3.20 & $8.47 \mathrm{~b}$ \\
\hline & Öküzgözü & $257.7 \mathrm{a}$ & 10.5 & 18.0 & $16.4 \mathrm{~b}$ & 3.18 & $9.33 \mathrm{~b}$ \\
\hline $\operatorname{LSD}_{(0.05)}$ & & 64.5 & ÖD & ÖD & 4.4 & ÖD & 1.83 \\
\hline \multirow{3}{*}{12 Eylül 2017} & Boğazkere & 191.1 & 10.0 & 16.2 & $18.2 \mathrm{~b}$ & $3.19 \mathrm{~b}$ & $9.93 \mathrm{a}$ \\
\hline & Kalecik Karası & 230.5 & 11.0 & 17.5 & $23.7 \mathrm{a}$ & $3.40 \mathrm{a}$ & $6.45 \mathrm{~b}$ \\
\hline & Öküzgözü & 293.2 & 10.9 & 18.3 & $19.0 \mathrm{~b}$ & $3.38 \mathrm{a}$ & $6.62 \mathrm{~b}$ \\
\hline $\operatorname{LSD}_{(0.05)}$ & & ÖD & ÖD & ÖD & 1.1 & 0.17 & 1.91 \\
\hline \multirow{3}{*}{18 Eylül 2017} & Boğazkere & $138.4 \mathrm{c}$ & 10.9 & 16.7 & 18.7 & $3.22 \mathrm{~b}$ & 8.51 \\
\hline & Kalecik Karası & $236.6 \mathrm{~b}$ & 11.4 & 19.4 & 24.3 & $3.48 \mathrm{a}$ & 6.08 \\
\hline & Öküzgözü & $316.0 \mathrm{a}$ & 11.0 & 19.1 & 19.5 & $3.25 \mathrm{~b}$ & 6.47 \\
\hline $\operatorname{LSD}_{(0.05)}$ & & 33.2 & ÖD & ÖD & ÖD & 0.20 & ÖD \\
\hline \multirow{2}{*}{25 Eylül 2017} & Boğazkere & $182.6 \mathrm{~b}$ & 11.5 & $17.0 \mathrm{~b}$ & 20.4 & $3.32 \mathrm{~b}$ & $7.11 \mathrm{a}$ \\
\hline & Öküzgözü & $350.2 \mathrm{a}$ & 11.9 & $20.8 \mathrm{a}$ & 22.2 & $3.54 \mathrm{a}$ & $5.55 \mathrm{~b}$ \\
\hline $\operatorname{LSD}_{(0.05)}$ & & 137.6 & ÖD & 2.0 & ÖD & 0.10 & 1.46 \\
\hline \multirow{3}{*}{ Hasat } & Boğazkere & $182.6 \mathrm{~b}$ & 11.5 & 17.0 & $20.4 \mathrm{~b}$ & $3.32 \mathrm{~b}$ & $7.11 \mathrm{a}$ \\
\hline & Kalecik Karası & $236.6 \mathrm{~b}$ & 11.4 & 19.4 & $24.3 \mathrm{a}$ & $3.48 \mathrm{a}$ & $6.08 \mathrm{~b}$ \\
\hline & Öküzgözü & $350.2 \mathrm{a}$ & 11.9 & 20.8 & $22.2 \mathrm{ab}$ & $3.54 \mathrm{a}$ & $5.55 \mathrm{~b}$ \\
\hline $\operatorname{LSD}_{(0.05)}$ & & 116.7 & ÖD & ÖD & 3.3 & 0.13 & 1.55 \\
\hline
\end{tabular}

*Boğazkere ben düşme

Çeşitlerde ben düşme'den olgunlaşamaya doğru pH değerleri artış göstermiștir. 2017 ve 2018 yılında $\mathrm{pH}$ değerleri hasat döneminde Boğazkere'de 3.32 - 3.30, Kalecik Karasında 3.48 - 3.34 ve Öküzgözü'nde 3.54 - 3.43 değerlerini almıştır. pH'daki artış çeşit ve yıl bazında farklılık göstermiştir (Çizelge 1 ve Çizelge 2). $\mathrm{pH}$, hasat döneminin belirlenmesinde etkili olan faktörlerden bir tanesidir (Ağaoğlu, 2002). pH değeri siyah ve kırmızı çeşitlerde Cooke ve Berg (1983)'e göre 3.1-3.6; Cox (1999)'a göre 3.4; Amerine ve ark. (1972)'na göre ise $\mathrm{pH}$ değerinin 3.4'ten aşağı olması gerektiğini belirtmişlerdir. Ben düşme döneminden itibaren tüm çeşitlerde olgunlaşmaya doğru $\mathrm{pH}$ değerinde bir artış meydana geldiği görülmüştür. Hasat döneminde tespit edilen $\mathrm{pH}$ değerleri çeşit ve yıla göre farklılık göstermiştir. 2 yılın hasat dönemindeki pH verileri Boğazkere çeşidinde: 3.443.29, Öküzgözü çeşidinde: $3.43-3.54$ ve Kalecik Karası çeşidinde: 3.54-3.36 olarak tespit edilmiştir. Çalışma sonucu elde edilen $\mathrm{pH}$ değerleri kaynaklarda belirtilen değerler arasında yer almıştır (Selli ve ark., 2001; Muhammad, 2014; Tahmaz, 2009; Yüksel, 2014; Kayalar, 2015; Gülcü ve ark., 2018; Çelik ve ark., 2019). 
Çizelge 2. Çeşitlerin 2018 yılı salkım ve şıra özellikleri

\begin{tabular}{|c|c|c|c|c|c|c|c|}
\hline \multirow{2}{*}{$\begin{array}{l}\text { Örnek alma } \\
\text { tarihi }\end{array}$} & \multirow[b]{2}{*}{ Çeşit } & \multicolumn{3}{|c|}{ Salkım } & \multirow[b]{2}{*}{$\begin{array}{l}\text { SÇKM } \\
(\%)\end{array}$} & \multirow[b]{2}{*}{$\mathrm{pH}$} & \multirow[b]{2}{*}{$\begin{array}{l}\text { Asit } \\
(\mathrm{g} / \mathrm{l})\end{array}$} \\
\hline & & $\begin{array}{l}\text { Salkım ağırlı̆̆ } \\
\text { (g) }\end{array}$ & $\begin{array}{c}\mathrm{En} \\
(\mathrm{cm})\end{array}$ & $\begin{array}{l}\text { Boy } \\
(\mathrm{cm})\end{array}$ & & & \\
\hline \multirow{3}{*}{$\begin{array}{l}10 \text { Ağustos } \\
2018\end{array}$} & Boğazkere & $104.0 \mathrm{c}$ & 8.0 & $10.2 \mathrm{~b}$ & $12.6 \mathrm{~b}$ & $2.94 \mathrm{~b}$ & $20.23 \mathrm{a}$ \\
\hline & Kalecik Karası & $190.0 \mathrm{a}$ & 7.8 & $10.6 \mathrm{~b}$ & $18.4 \mathrm{a}$ & $3.19 \mathrm{a}$ & $8.90 \mathrm{~b}$ \\
\hline & Öküzgözü & $158.8 \mathrm{~b}$ & 7.7 & $12.1 \mathrm{a}$ & $13.5 \mathrm{~b}$ & $3.10 \mathrm{a}$ & $12.26 \mathrm{~b}$ \\
\hline $\operatorname{LSD}_{(0.05)}$ & & 28.1 & ÖD & 1.3 & 3.2 & 0.11 & 4.60 \\
\hline \multirow{3}{*}{$\begin{array}{l}17 \text { Ağustos } \\
2018\end{array}$} & Boğazkere & $171.8 \mathrm{~b}$ & $9.1 \mathrm{a}$ & $11.6 \mathrm{ab}$ & $17.4 \mathrm{~b}$ & $2.98 \mathrm{~b}$ & $16.28 \mathrm{a}$ \\
\hline & Kalecik Karası & $197.5 \mathrm{~b}$ & $7.8 \mathrm{~b}$ & $10.7 \mathrm{~b}$ & $20.9 \mathrm{a}$ & $3.21 \mathrm{a}$ & $9.22 \mathrm{~b}$ \\
\hline & Öküzgözü & $311.1 \mathrm{a}$ & $9.1 \mathrm{a}$ & $13.4 \mathrm{a}$ & $14.1 \mathrm{~b}$ & $3.11 \mathrm{ab}$ & $6.55 \mathrm{~b}$ \\
\hline $\operatorname{LSD}_{(0.05)}$ & & 49.6 & 1.0 & 1.8 & 3.7 & 0.16 & 4.52 \\
\hline \multirow{3}{*}{$\begin{array}{l}31 \text { Ağustos } \\
2018\end{array}$} & Boğazkere & $278.7 \mathrm{ab}$ & 10.5 & 13.1 & $16.4 \mathrm{~b}$ & $3.01 \mathrm{~b}$ & $10.71 \mathrm{a}$ \\
\hline & Kalecik Karası & $198.2 \mathrm{~b}$ & 8.8 & 11.8 & $23.7 \mathrm{a}$ & $3.34 \mathrm{a}$ & $9.60 \mathrm{~b}$ \\
\hline & Öküzgözü & $346.9 \mathrm{a}$ & 10.4 & 14.5 & $17.1 \mathrm{~b}$ & $3.28 \mathrm{a}$ & $7.45 \mathrm{~b}$ \\
\hline $\operatorname{LSD}_{(0.05)}$ & & 91.5 & ÖD & ÖD & 2.0 & 0.16 & 1.30 \\
\hline \multirow{2}{*}{14 Eylül 2018} & Boğazkere & 325.5 & 14.6 & $17.8 \mathrm{~b}$ & 19.3 & $3.25 \mathrm{~b}$ & 6.87 \\
\hline & Öküzgözü & 414.9 & 16.4 & $19.4 \mathrm{a}$ & 20.1 & $3.35 \mathrm{a}$ & 7.32 \\
\hline $\operatorname{LSD}_{(0.05)}$ & & ÖD & ÖD & 1.2 & ÖD & 0.01 & ÖD \\
\hline \multirow{2}{*}{28 Eylül 2018} & Boğazkere & 375.0 & 14.9 & $17.7 \mathrm{~b}$ & 21.1 & 3.30 & 4.84 \\
\hline & Öküzgözü & 424.2 & 16.9 & $20.6 \mathrm{a}$ & 21.4 & 3.43 & 5.70 \\
\hline $\operatorname{LSD}_{(0.05)}$ & & ÖD & ÖD & 2.4 & ÖD & ÖD & ÖD \\
\hline \multirow{3}{*}{ Hasat } & Boğazkere & $375.0 \mathrm{a}$ & $14.9 \mathrm{~b}$ & 17.7 b & $21.1 \mathrm{~b}$ & 3.30 & $4.84 \mathrm{~b}$ \\
\hline & Kalecik Karası & $198.2 \mathrm{~b}$ & $8.8 \mathrm{c}$ & $11.8 \mathrm{c}$ & $23.7 \mathrm{a}$ & 3.34 & $7.60 \mathrm{a}$ \\
\hline & Öküzgözü & $424.2 \mathrm{a}$ & $16.9 \mathrm{a}$ & $20.6 \mathrm{a}$ & $21.4 \mathrm{~b}$ & 3.43 & $5.70 \mathrm{~b}$ \\
\hline $\operatorname{LSD}_{(0.05)}$ & & 148.4 & 1.8 & 1.8 & 1.6 & ÖD & 1.08 \\
\hline
\end{tabular}

Ben düșme döneminden hasada kadar olan süre içerisinde tüm çeşitlerde; toplam asitlik seviyesi azalmıș, hasat öncesi ve hasat zamanındaki dönemde hemen hemen sabit bir düzeyde kalmıştır. Hasat döneminde hem yıl hem de çeșitler bakımından farklılık göstermiştir. 1'nci ve 2'nci yılda toplam asitlik miktarı Boğazkere'de hasat zamanında 7.114.84, Kalecik Karası'nda 6.08-7.60, Öküzgözü'nde 5.55-5.70 g/l olarak tespit edilmiştir (Çizelge 1 ve Çizelge 2). Şaraplık üzümlerde asitlik değeri konusunda araştırıcılar farklı görüşleri savunabilmektedir. Amerine ve ark. (1972), şarap yapımı için, şırada asit miktarının: $6.5 \mathrm{~g} / \mathrm{l}$ 'den yüksek olması gerektiğini; Boulton ve ark. (1996), Bu değerin: 6.5-7.5 g/l aralığında olabileceğini; Cox (1999), Beyaz üzüm çeşitlerinde asitliğin: \% 0.650.85 arasında, renkli çeşitlerde ise: \% 0.60-0.80 arasında olması gerektiğini; Amerine ve ark. (1980), 3-15 g/l aralığında, Ough ve Amerine (1988), 6-9 g/l aralığında olması gerektiğini rapor etmişlerdir. Çalışmanın ikinci yılında Boğazkere'de toplam asitlik miktarı düşük çıkmıştır. Bu durum Boğazkere'nin daha geç olgunlaşan bir çeşit olması ile ilişkilendirilmektedir. Boğazkere'de tespit edilen toplam asitlik değerleri; Şen (2008), Yüksel (2014), Şan (2016) ve Ünal ve Şener (2016)'in'ın bulgularından daha yüksek görülmekte fakat diğer literatürle ile uyumlu görülmektedir.

1103 P anacı üzerine aşılı Boğazkere, Kalecik Karası ve Öküzgözü çeşitlerine ait tane özellikleri Çizelge 3 ve 4'de verilmiștir.

2017 yılında tane eni, tane boyu ve tane ağırlığına ait veriler, çeşitler arasında istatistiksel açıdan önemli bulunmuştur. Her iki yılın tane özellikleri dikkate alındığında bütün dönemlerde en yüksek değerlerin Öküzgözü çeşidinde gerçekleștiği görülmektedir. Birinci yılın verilerinde Boğazkere ve Kalecik Karası çeşitlerinin tane eni, tane boyu ve tane ağırlığı ile ilgili değerler birbirine yakın iken, 2'nci yılda Kalecik Karası'nda daha yüksek değerler ortaya çıkmıştır. Genel olarak çeşitlerin 2018 yılı tane eni, tane boyu ve tane ağırlığına ait elde edilen verileri; 2017 yılına göre daha yüksek çıkmıştır (Çizelge 3 ve 4). Çeşitlerin orjin bölgelerinde yapılan çalışmalarda Öküzgözü üzüm çeşidinin 200 tane ağırlığının 300976 g (Deryaoğlu ve Canbaş, 2003), Boğazkere çeşidinin 200 tane ağırlığının 305-626 g (Deryaoğlu ve Canbaş, 2004), Kalecik Karası çeşidinin ise 100 tane ağırlığının 151-221 g (Karataş ve ark., 2010) arasında değiştiği belirlenmiştir. Elde edilen sonuçlara göre çeşitlerin tane ağırlıkları önceki çalışmalarda belirtilen sınırlar içerisinde kalmıştır (2018 yılı Boğazkere çeşidinin tane ağırlığı hariç). 
Çizelge 3. Çeşitlerin 2017 yılı tane özellikleri

\begin{tabular}{|c|c|c|c|c|c|}
\hline \multirow{2}{*}{$\begin{array}{l}\text { Örnek alma } \\
\text { tarihi }\end{array}$} & \multirow{2}{*}{ Çeşit } & \multicolumn{4}{|c|}{ Tane } \\
\hline & & En $(\mathrm{mm})$ & Boy $(\mathrm{mm})$ & Ağırlık (g) & Sertlik (NW) \\
\hline \multirow{3}{*}{$\begin{array}{c}15 \text { Ağustos } \\
2017\end{array}$} & Boğazkere & $8.9 \mathrm{~b}$ & $11.3 \mathrm{~b}$ & $0.69 \mathrm{c}$ & $1.77 \mathrm{a}$ \\
\hline & Kalecik Karası & $11.2 \mathrm{a}$ & $11.4 \mathrm{~b}$ & $0.99 \mathrm{~b}$ & $1.08 \mathrm{c}$ \\
\hline & Öküzgözü & $11.9 \mathrm{a}$ & $13.8 \mathrm{a}$ & $1.44 \mathrm{a}$ & $1.42 \mathrm{~b}$ \\
\hline $\operatorname{LSD}_{(0.05)}$ & & 1.9 & 1.2 & 0.33 & 0.30 \\
\hline \multirow{3}{*}{$\begin{array}{c}22 \text { Ağustos } \\
2017\end{array}$} & Boğazkere & $9.3 \mathrm{~b}$ & $11.0 \mathrm{~b}$ & $0.79 \mathrm{~b}$ & 1.28 \\
\hline & Kalecik Karası & $11.3 \mathrm{a}$ & $11.5 \mathrm{~b}$ & $1.20 \mathrm{~b}$ & 0.62 \\
\hline & Öküzgözü & $12.4 \mathrm{a}$ & $14.2 \mathrm{a}$ & $1.9 \mathrm{a}$ & 0.90 \\
\hline $\operatorname{LSD}_{(0.05)}$ & & 1.5 & 0.9 & 0.56 & ÖD \\
\hline \multirow{3}{*}{$\begin{array}{l}29 \text { Ağustos } \\
2017\end{array}$} & Boğazkere & $9.7 \mathrm{c}$ & $11.8 \mathrm{~b}$ & $0.77 \mathrm{c}$ & $1.10 \mathrm{a}$ \\
\hline & Kalecik Karası & $11.8 \mathrm{~b}$ & $12.6 \mathrm{~b}$ & $1.37 \mathrm{~b}$ & $0.60 \mathrm{~b}$ \\
\hline & Öküzgözü & $13.5 \mathrm{a}$ & $15.0 \mathrm{a}$ & $1.89 \mathrm{a}$ & $0.50 \mathrm{~b}$ \\
\hline $\operatorname{LSD}_{(0.05)}$ & & 1.0 & 1.2 & 0.35 & 0.32 \\
\hline \multirow{3}{*}{05 Eylül 2017} & Boğazkere & $11.1 \mathrm{~b}$ & $12.1 \mathrm{~b}$ & $1.05 \mathrm{~b}$ & $0.59 \mathrm{a}$ \\
\hline & Kalecik Karası & $11.7 \mathrm{~b}$ & $12.4 \mathrm{~b}$ & $0.36 \mathrm{~b}$ & $0.36 \mathrm{~b}$ \\
\hline & Öküzgözü & $14.6 \mathrm{a}$ & $16.4 \mathrm{a}$ & $2.57 \mathrm{a}$ & $0.35 \mathrm{~b}$ \\
\hline $\operatorname{LSD}_{(0.05)}$ & & 0.7 & 1.6 & 0.50 & 0.06 \\
\hline \multirow{3}{*}{12 Eylül 2017} & Boğazkere & $12.3 \mathrm{~b}$ & $13.4 \mathrm{~b}$ & $1.87 \mathrm{~b}$ & $0.57 \mathrm{a}$ \\
\hline & Kalecik Karası & $12.3 \mathrm{~b}$ & $11.9 \mathrm{~b}$ & $1.38 \mathrm{~b}$ & $0.31 \mathrm{~b}$ \\
\hline & Öküzgözü & $14.9 \mathrm{a}$ & $17.0 \mathrm{a}$ & $2.52 \mathrm{a}$ & $0.31 \mathrm{~b}$ \\
\hline $\operatorname{LSD}_{(0.05)}$ & & 1.4 & 2.0 & 0.72 & 0.09 \\
\hline \multirow{3}{*}{18 Eylül 2017} & Boğazkere & $11.1 \mathrm{c}$ & $12.9 \mathrm{~b}$ & $1.36 \mathrm{~b}$ & 0.55 \\
\hline & Kalecik Karası & $12.2 \mathrm{~b}$ & $12.1 \mathrm{~b}$ & $1.42 \mathrm{~b}$ & 0.70 \\
\hline & Öküzgözü & $14.6 \mathrm{a}$ & $16.1 \mathrm{a}$ & $3.02 \mathrm{a}$ & 0.53 \\
\hline $\operatorname{LSD}_{(0.05)}$ & & 1.0 & 1.0 & 0.38 & ÖD \\
\hline \multirow{2}{*}{25 Eylül 2017} & Boğazkere & $12.6 \mathrm{a}$ & $14.3 \mathrm{~b}$ & $1.67 \mathrm{~b}$ & 0.52 \\
\hline & Öküzgözü & $15.7 \mathrm{a}$ & $17.1 \mathrm{a}$ & $3.07 \mathrm{a}$ & 0.55 \\
\hline $\operatorname{LSD}_{(0.05)}$ & & 3.1 & 2.2 & 1.33 & ÖD \\
\hline \multirow{3}{*}{ Hasat } & Boğazkere & $12.6 \mathrm{~b}$ & $14.3 \mathrm{~b}$ & $1.67 \mathrm{~b}$ & 0.52 \\
\hline & Kalecik Karası & $12.2 \mathrm{~b}$ & $12.1 \mathrm{c}$ & $1.42 \mathrm{~b}$ & 0.70 \\
\hline & Öküzgözü & $15.7 \mathrm{a}$ & $17.1 \mathrm{a}$ & $3.07 \mathrm{a}$ & 0.55 \\
\hline $\operatorname{LSD}_{(0.05)}$ & & 2.4 & 1.6 & 1.12 & ÖD \\
\hline
\end{tabular}

2017 ve 2018 yıllarında, 1103 Paulsen anacı üzerine aşılı Boğazkere, Kalecik Karası ve Öküzgözü çeşitlerinin toplam fenolik, flavonoid ve antosiyanin içerikleri Şekil 4, Şekil 5 ve Şekil 6'da verilmiştir.

Hasat zamanları dikkate alındığında 2017 ve 2018 yıllarında incelenen özelliklerin hepsi istatistiki açıdan önemli bulunmuştur. 1103 Paulsen anacına aşllı çeşitler içerisinde en fazla toplam fenolik madde içeriği 2017 yılında Boğazkere çeşidinde bulunurken (189 mg GAE/100 g) 2018 yllında Öküzgözü çeşidinde (144 mg GAE/100 g) bulunmuştur (Şekil 4). Çeşitler arasında kabukta flavonoid içerikleri bakımından her iki yılda da en yüksek değerler Öküzgözü çeşinde tespit edilmiștir (134 mg QUE/g $111 \mathrm{mg} \mathrm{QUE} / \mathrm{g}$ ) (Şekil 5). Kabuktaki antosiyanin miktarı 2017 yılında Boğazkere'de yüksek çıkarken (12.6 mg/g), 2018 yılında Öküzgözü’nde (16.8 mg/g) yüksek çıkmıştır (Şekil 6). Tane iriliği, tanenin içerdiği su miktarı, kabuk kalınlığı, çekirdek sayısı ve ağırlığı (Polat, 2016), çeşidin olgunluk düzeyi, yöre, iklim, toprağın içerdiği besin maddeleri kapsamı, sulama gibi faktörler toplam fenolik madde miktarı üzerinde rol almaktadır (Waterhouse, 2002; Yabacı Karaoğlan, 2015). Birçok araştırmacı tarafından toplam fenolik maddenin olgunlaşmaya doğru bir azalış gösterdiği ve hasat döneminde çeşit ve yll bazında değişkenlik gösterdiği belirtilmiştir (Deryaoğlu ve Canbaș, 2003; Uluocak, 2010; Cangi ve ark., 2011; Aydın, 2015; Otağ, 2015; Bekar ve Bayram, 2016; Polat, 2016). Toplam Fenolik bileşik içeriği beyaz üzümlerde: $50-200 \mathrm{mg} / \mathrm{l}$ (Shadidi ve Naczk, 1995; Kayalar, 2015) siyah üzümlerde ise: $920 \mathrm{mg} / \mathrm{kg}^{\prime}$ dır (Faikoğlu, 2014). Elde edile veriler dikkate alındığında fenolik madde miktarları daha öce yapılan çalışmalarla (Deryaoğlu ve Canbaş, 2003; ; Uluocak, 2010; Cangi ve ark., 2011; Aydın, 2015; Keskin ve ark., 2013; Otağ, 2015; Bekar ve Bayram, 2016; Polat, 2016; Uzun ve ark., 2019a; Uzun ve ark., 2019b) uyum içerisindedir. Flavonoid miktarı; üzümde olgunlaşmaya doğru azalmakta ve toplam flavonoid miktarı beyaz çeşitlere nazaran siyah çeşitlerde daha yüksek değerlerde bulunmaktadır (Aydın, 2015; Polat, 2016). Flavanoid içeriği ile ilgili bulgular literatür ile uyumludur (Moskowitz ve Hrazdina, 1981; Keskin ve ark., 2013; Kunter ve ark., 2013; Ateş, 2015; Aydın, 2015; Polat, 2016; Uzun ve ark., 2019a; Uzun ve ark., 2019b). 
Çizelge 4. Çeşitlerin 2018 yılı tane özellikleri

\begin{tabular}{|c|c|c|c|c|c|}
\hline \multirow{2}{*}{$\begin{array}{c}\text { Örnek alma } \\
\text { tarihi }\end{array}$} & \multirow[b]{2}{*}{ Çeşit } & \multicolumn{4}{|c|}{ Tane } \\
\hline & & En $(\mathrm{mm})$ & Boy $(\mathrm{mm})$ & Ağırlık (g) & Sertlik (NW) \\
\hline \multirow{3}{*}{$\begin{array}{c}10 \text { Ağustos } \\
2018\end{array}$} & Boğazkere & 12.8 & 13.8 & 1.69 & 0.48 \\
\hline & Kalecik Karası & 13.4 & 14.2 & 1.84 & 0.28 \\
\hline & Öküzgözü & 13.8 & 15.0 & 2.11 & 0.45 \\
\hline $\operatorname{LSD}_{(0.05)}$ & & ÖD & ÖD & ÖD & ÖD \\
\hline \multirow{3}{*}{$\begin{array}{l}17 \text { Ağustos } \\
2018\end{array}$} & Boğazkere & $13.0 \mathrm{c}$ & $14.0 \mathrm{~b}$ & $1.72 \mathrm{~b}$ & 0.42 \\
\hline & Kalecik Karası & $13.9 \mathrm{~b}$ & $14.6 \mathrm{~b}$ & $1.96 \mathrm{~b}$ & 0.29 \\
\hline & Öküzgözü & $14.6 \mathrm{a}$ & $16.7 \mathrm{a}$ & $2.96 \mathrm{a}$ & 0.33 \\
\hline $\operatorname{LSD}_{(0.05)}$ & & 0.7 & 1.1 & 0.45 & ÖD \\
\hline \multirow{3}{*}{$\begin{array}{l}31 \text { Ağustos } \\
2018\end{array}$} & Boğazkere & $13.8 \mathrm{c}$ & $15.0 \mathrm{~b}$ & 2.23 & 0.34 \\
\hline & Kalecik Karası & $14.4 \mathrm{~b}$ & $15.4 \mathrm{~b}$ & 2.17 & 0.26 \\
\hline & Öküzgözü & $15.2 \mathrm{a}$ & $16.8 \mathrm{a}$ & 3.07 & 0.32 \\
\hline $\operatorname{LSD}_{(0.05)}$ & & 0.6 & 1.2 & ÖD & ÖD \\
\hline \multirow{2}{*}{14 Eylül 2018} & Boğazkere & 14.1 & 15.8 & 2.27 & $0.28 \mathrm{a}$ \\
\hline & Öküzgözü & 16.6 & 18.8 & 3.52 & $0.21 \mathrm{~b}$ \\
\hline $\operatorname{LSD}_{(0.05)}$ & & ÖD & ÖD & ÖD & 0.04 \\
\hline \multirow{2}{*}{28 Eylül 2018} & Boğazkere & $14.9 \mathrm{~b}$ & 16.1 & 2.42 & 0.22 \\
\hline & Öküzgözü & $16.7 \mathrm{a}$ & 19.0 & 3.56 & 0.16 \\
\hline $\operatorname{LSD}_{(0.05)}$ & & 1.3 & ÖD & ÖD & ÖD \\
\hline \multirow{3}{*}{ Hasat } & Boğazkere & $14.9 \mathrm{~b}$ & $16.1 \mathrm{~b}$ & $2.42 \mathrm{~b}$ & $0.22 \mathrm{a}$ \\
\hline & Kalecik Karası & $14.4 \mathrm{~b}$ & $15.4 \mathrm{~b}$ & $2.17 \mathrm{~b}$ & $0.26 \mathrm{a}$ \\
\hline & Öküzgözü & $16.7 \mathrm{a}$ & $19.0 \mathrm{a}$ & $3.56 \mathrm{a}$ & $0.16 \mathrm{~b}$ \\
\hline $\operatorname{LSD}_{(0.05)}$ & & 0.7 & 1.8 & 0.69 & 0.05 \\
\hline
\end{tabular}
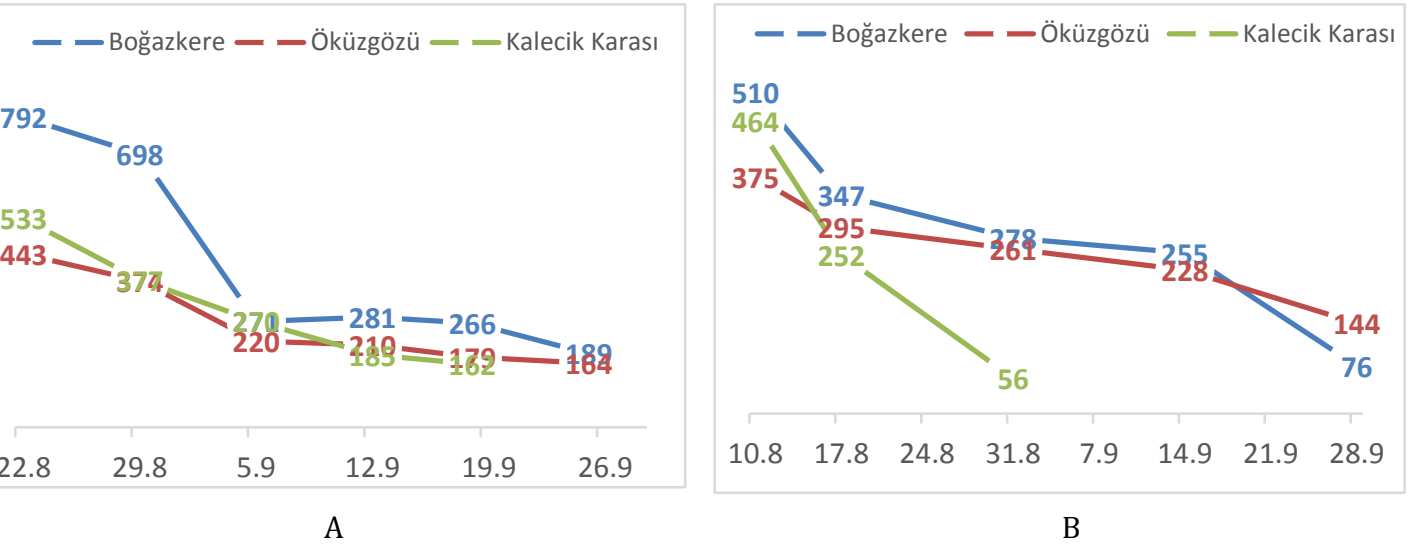

Şekil 1. Çeşitlerin zamana bağlı olarak toplam fenolik madde değişimi (GAE/100 g) (A: 2017 yıll; B: 2018 yll)
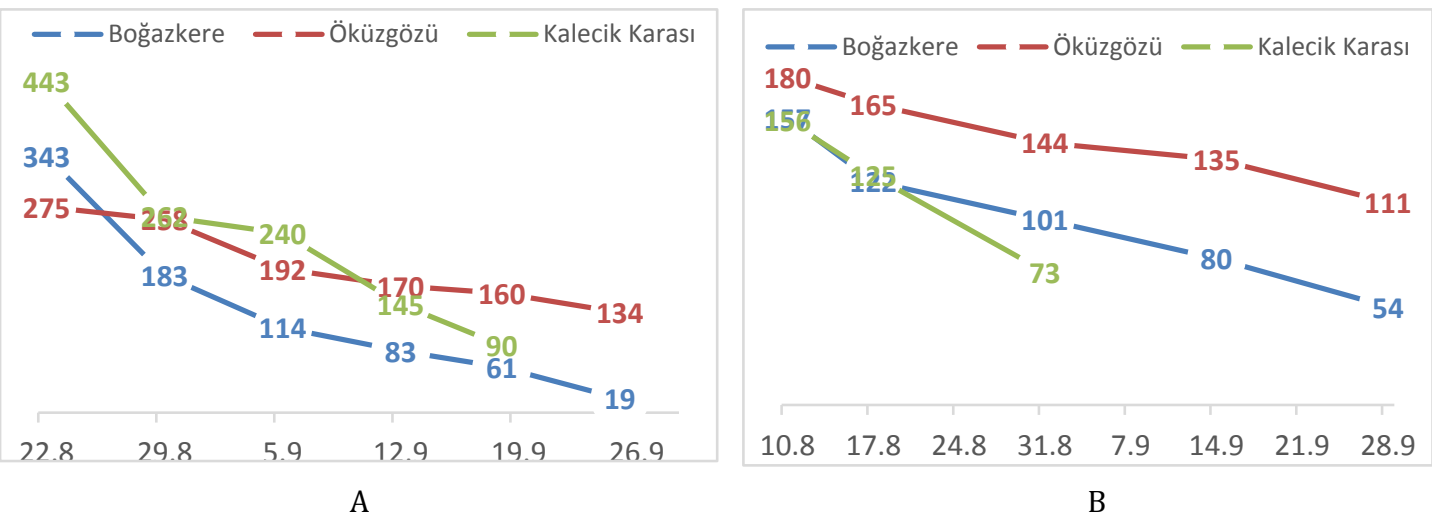

Şekil 2. Çeşitlerin zamana bağlı olarak flavanoid (kabuk) değişimi (mg QUE/g) (A: 2017 yllı; B: 2018 yllı) 


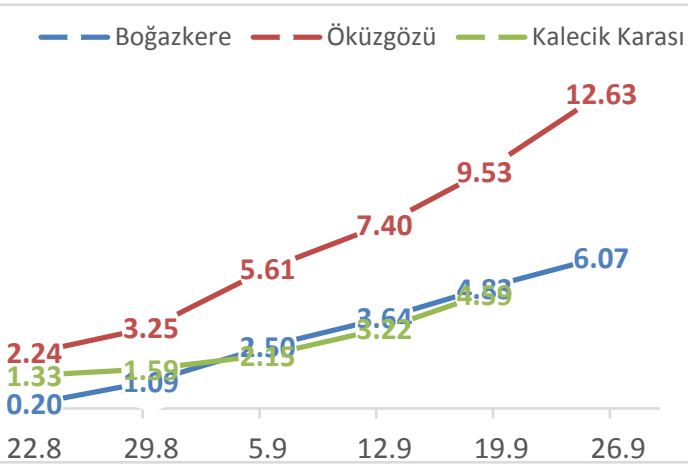

A

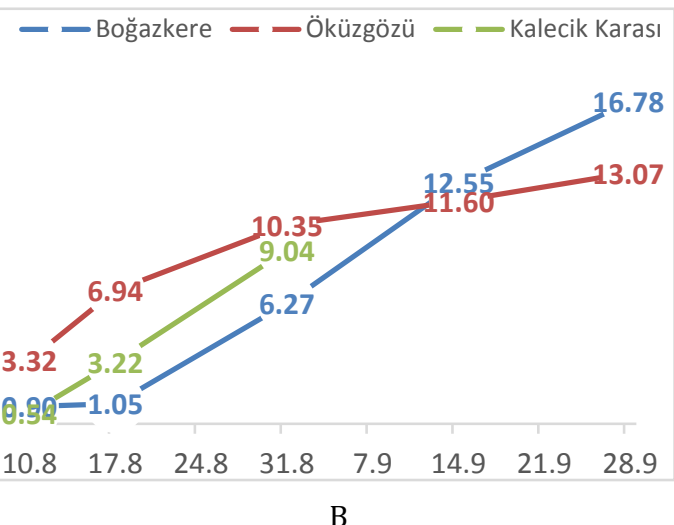

Şekil 3. Çeşitlerin zamana bağlı olarak Antosiyanin (kabuk) değişimi (mg/g) (A: 2017 ylli; B: 2018 ylli)

Çalıșmanın yapıldığı yerde 2017 yılında genel olarak, çeşitlerde uyanma, mart ayı sonunda; sürme, nisanın ilk haftasında; tam çiçeklenme, haziranın ikinci haftasında; tane tutumu, haziranın üçüncü haftasında; ben düşme, temmuz sonu-ağustos başında; hasat, eylül ayının ikinci haftası ile ekim ayının üçüncü haftası arasında ve yaprak dökümü ise kasım ayının ikinci ve üçüncü haftasında meydana gelmiştir. 2018 yllında ise iklimsel değişiklikler nedeniyle fenolojik dönemler yaklaşık iki hafta öne alınmıştır. Bu durum çeşitlere göre değişmekle birlikte hasat zamanının 2-14 gün erkene alınmasına neden olmuştur (Çizelge 5).

Çizelge 5. Çalışmaya konu olan çeșitlerin Uyanma, hasat ve yaprak döküm tarihleri

\begin{tabular}{ccccc}
\hline Çeşitler & Yll & Uyanma & Hasat & Yaprak Dökümü \\
\hline \multirow{2}{*}{ Boğazkere } & 2017 & 29 Mart & 12 -19 Ekim & 23 Kasım \\
& 2018 & 18 Mart & 15-17 Ekim & 23 Kasım \\
\hline \multirow{2}{*}{ Kalecik Karası } & 2017 & 25 Nisan & 23 Eylül-4 Ekim & 13 Kasım \\
& 2018 & 6 Nisan & 12 Eylül & 15 Kasım \\
\hline \multirow{2}{*}{ Öküzgözü } & 2017 & 6 Nisan & 27 Eylül -9 Ekim & 22 Kasım \\
& 2018 & 25 Mart & 23 Eylül & 23 Kasım \\
\hline
\end{tabular}

2017 yılında geç uyanma geç hasat; 2018 yılında erken uyanma erken hasat meydana gelmiștir. Her iki yılda geçen süre ise birbirine çok yakın olmuştur. 2018 yılında sıcaklıkların fazla olması ve hasat sonrasinda da bu durumun devam etmesi; hem vegetasyonu uzatmış hem de günlerin EST değerini artırmıştır (Çizelge 6). Üzümlerin olgunlaşması yıllık iklimsel olaylardan önemli derecede etkilenebilmektedir. Uyanma, çiçeklenme, ben düşme ve olgunlaşma üzerinde en önemli iklimsel parametre; sıcaklıktır (Jarvis ve ark, 2017). Üzüm çeşitlerinin farklı zamanlarda olgunlaşması; çeşitlerin farklı sıcaklık, yağış ve güneşlenme süresi ile ilgili isteklerinden kaynaklanmaktadır (Winkler ve ark., 1974; Çelik ve ark., 1998). Üzümün olgunlaşma zamanı yerel iklim şartları ile yakından ilişkilidir. Fenolojik gelişme dönemleri, çeşitten çeşide değişen genetik bir özelliktir (Van Leeuwen ve ark., 2008). Aynı çeşitlerde yıllar arasında görülen EST farklılıklarına sulama ve son yıllardaki sıcaklık artışlarının etkili olduğu bildirilmektedir (Çelik ve ark., 2005). Bu çalışmada yıllara göre yapılan kültürel işlemlerde çok büyük farklıllklar bulunmamaktadır. Bu nedenle EST değerlerindeki farklılıklar sıcaklık değerlerindeki değişimden kaynaklandığını düşündürmektedir.

Çalışmaya konu olan üzüm çeşitlerinden Kalecik Karası Ankara'nın, Öküzgözü ve Boğazkere ise Diyarbakır ve Elazığ illerinin en önemli çeşitleri olup (Çelik ve ark., 1998; Çelik ve ark., 2005; Ateș, 2015) uluslararası piyasada rekabet etme şansı en yüksek çeşitlerdir. Bu nedenle bu çeşitler Türkiye'nin farklı bağ bölgelerinde yetiştirilmeye çalışılmaktadır. $\mathrm{Bu}$ çalışmada Kırşehir koşullarında yetiştirilen 
Öküzgözü, Boğazkere ve Kalecik Karası çeşitlerinden elde edilen veriler, çeşitlerin asıl yetiştirildiği yerlerden elde edilen verilere yakın değerler alınmıştır (Deryaoğlu ve Canbaş, 2003; Deryaoğlu ve Canbaş, 2004; Çelik ve ark., 2005; Özdemir ve Sessiz,
2018). Bu durum Kırşehir ilinin çok eski bir bağcılık merkezi olması ve ikliminin özellikle şaraplık üzüm yetiştiriciliği bakımından istenilen sınırlar içerisinde kalmasından kaynaklanmaktadır.

Çizelge 6. Çalışmaya konu olan çeşitlerin EST değerleri (dg)

\begin{tabular}{cccc}
\hline Çeşitler & Yll & U-H & U-YD \\
\hline \multirow{2}{*}{ Boğazkere } & 2017 & 1556.7 & 1589.7 \\
& 2018 & 1709.4 & 1763.9 \\
\hline \multirow{2}{*}{ Kalecik Karası } & 2017 & 1520.8 & 1574.2 \\
\hline \multirow{2}{*}{ Öküzgözü } & 2018 & 1477.4 & 1751.4 \\
& 2017 & 1527.5 & 1581.8 \\
\hline
\end{tabular}

U-H: Uyanma-Hasat, U-YD: Uyanma-Yaprak dökümü

\section{Sonuç}

Bu çalışmadan aşağıdaki sonuçlar çıkarılabilir.

- Bağlarda fenolojik dönemler ve EST değerleri çeşitlere göre değişmektedir.

- Bir çeşidin fenolojik dönemleri ve EST değerleri ise yıllara göre değișebilmektedir.

- Üzümlerde ben düşme döneminden olgunluğa doğru salkım ağırlığı, tane ağırlığl, SÇKM ve antosiyanin artarken tane eti sertliği, şıradaki asit miktarı, fenolik ve flavanoid miktarı ise azalma eğilimindedir.

- Üzümlerde olgunluk zamanı, SÇKM, asitlik, salkım ve tane özellikleri, fenolik ve flavonoidler yıldan yıla farklı olabilmektedir.

- Fenolik madde miktarı çeşitlere göre değişmektedir.

- Üzümlerde olgunluğa doğru fenolik madde içerikleri azalmaktadır.

- Flavonoid miktarı çeşitlere göre değişmektedir.

- Üzümlerde olgunluğa doğru flavonoid madde içerikleri azalmaktadır.

- İki yıl ortalamasına göre ben düșme ile hasat arasında salkım ağırlığında Boğazkere çeşidinde 3.0 kat, Kalecik Karasında 1.5 kat, Öküzgözü çeşidinde 2.5 kat; tane ağırlığında Boğazkere çeşidinde 1.8 kat, Kalecik Karasında 1.3 kat, Öküzgözü çeşidinde 1.9 kat artış meydana gelmiştir.

\section{Teşekkür}

“Bu çalışma Tokat Gaziosmanpaşa Üniversitesi Bilimsel Araştırma Projeleri Koordinasyon Birimince Desteklenmiştir. Proje Numarası: 2018 / 44.

\section{Kaynaklar}

Ağaoğlu, Y.S. (2002). Bilimsel ve uygulamalı bağcılık. (Cilt:2). Asma Fizyolojisi (1), Kavaklıdere Eğitim Yayınları, No:5. Ankara, 320-383.

Amerine, M. A., Berg, H.W. \& Cruess, W.V. (1972). The technology of wine making. pp. 96-150, The AVI Publishing Company, Connecticut.

Amerine, M.A., Berg, H.W., Kunkee, R.E., Ough, C.S., Singletonnes, V.L. \& Webb, A.D. (1980). The technology of winemaking, 4th Edition. AVI Publ. Co. Inc.

Ateş, S. (2015). Farklı üzüm çeşitlerinin olgunlaşma sürecinde polifenol içerikleri ile antioksidan kapasitelerinin belirlenmesi. (Yüksek lisans tezi). İnönü Üniversitesi, Fen Bilimleri Enstitüsü, Kimya Anabilim Dalı, Malatya.

Aydın, M. (2015). Amasya'da yetiştirilen üzüm çeşitlerinin farklı olgunluk dönemlerindeki bazı kimyasal içeriklerinin belirlenmesi.(Yüksek lisans tezi). Gaziosmanpaşa Üniversitesi, Fen Bilimleri Enstitüsü, Bahçe Bitkileri Anabilimdalı, Tokat.

Bekar, T. (2017). Tokat merkezde yetiştirilen bazı şaraplık üzüm çeşitlerinin fenolojik gelişme evreleri. Türkiye Teknoloji ve Uygulamalı Bilimler Dergisi, 1(2), 73-78.

Bekar, T., Bayram, M. (2016). Ticari maya ilave edilerek ve edilmeden Narince üzüm çeşidinden üretilen şarapların fitokimyasal özelliklerinin belirlenmesi. Gaziosmanpaşa Bilimsel Araștırma Dergisi, 09-24.

Bino, R.J., Ric de Vos, C.H., Lieberman, M., Robert, D.H., Bovy, A., Jonker, H.H., Tukinov, Y., Lommen, A., Moco, S., \& Levin, I. (2005). The lighthyperresponsive high pigment-2dg mutation of 
tomato: alterations in the fruit metabolome. New Phytologist, 166, 427-438.

Borazan, A.A. (2008). Öküzgözü üzümünden şarap üretiminde fermantasyon şartlarının antioksidan aktivite ve polifenoller üzerine etkisi. (Doktora tezi). Anadolu Üniversitesi, Fen Bilimleri Enstitüsü, Kimya Mühendisliği Anabilim Dalı, Eskișehir.

Boulton, R.B., Singleton, V.L., Bisson, L.F., \& Kunkee, R.E. (1996). Principles and practises of wine making, Chaman Hall, 604 p. New York.

Bozdoğan, A., Ünal, M.Ü., Ertan, H., \& Cabaroğlu, T. (2005). Öküzgözü ve Boğazkere üzümleri karışımının şaraba işlenmesinde cibre fermantasyonu süresinin fenol bileşikleri üzerine etkisi. Gıda, 30(1), 63-69.

Cangi, R., Saraçoğlu, O., Uluocak, E., Kılıç, D., \& Şen, A. (2011). Kazova (Tokat) yöresinde yetiştirilen bazı şaraplık üzüm çeşitlerinde olgunlaşma sırasında meydana gelen kimyasal değişmeler. Iğdır Üniversitesi, Fen Bilimleri Enstitüsü Dergisi, 1(3), 914.

Cemeroğlu, B. (1992). Meyve ve sebze işleme endüstrisinde temel analiz metotları. Biltav Üniversite Kitapları Serisi, No: 02-2. Ankara, 381.

Cooke, G.M., \& Berg, H.W. (1983). A re-examination of varietal table wine processing practices in California. i. grape standards. grape and juice treatment and fermentation. American Journal of Enology and Viticulture, 34(4), 249-256.

Cox, J. (1999). From vines to wines. storey books; 3rd Revised edition. 256p.

Çelik, H. (1996). Bağcılıkta anaç kullanımı ve yetiştiricilikteki önemi. Anadolu Journal of Aegean Agricultural Research Institute, 6(2), 127-148.

Çelik, H., Ağaoğlu, Y.S., Fidan, Y., Marasalı, B. \& Söylemezoğlu, G.(1998). Genel bağcılık, Sun Fidan A.Ş. Mesleki Kitaplar Serisi:1. Ankara.

Çelik, H., Söylemezoğlu, G., Çetiner, H., Kunter, B., \& Çakır, A. (2005). Bazı üzüm çeşitlerinin Kalecik (Ankara) koşullarındaki fenolojik özellikleri ile etkili sıcaklık toplamı (EST) isteklerinin belirlenmesi. Türkiye 6 . Bağcılık Sempozyumu Bildiri Kitabı (2),390-397, 19-23 Eylül 2005, Tekirdağ.

Çelik, S. (2011). Bağcılık Ampeloji (Cilt:1), Avcı Ofset. İstanbul, 273-309.

Çelik, Z.D. (2012). Malolaktik fermantasyonun ve iki farklı malolaktik bakteri kültürünün (Oenococcus oeni vp41, Oenococcus oeni pn4), Kalecik Karası şarabının aroma bileşikleri üzerine etkisi. (Yüksek lisans tezi). Çukurova Üniversitesi, Fen Bilimleri Enstitüsü, Biyoteknoloji Anabilim Dalı, Adana.
Çelik, H., Kunter, B., Selli, S., Keskin, N., Akbaş, B., \& Değirmenci, K. (2019). Kalecik Karası üzüm çeşidinde klon seleksiyonu ve seçilen klonlara ait ana damızlık parselinin oluşturulması. Tarım Bilimlerinde Güncel Araştırma ve Değerlendirmeler, (Eds: Kunter B, Keskin N) Stamparija Ivpe, Cetinje, pp.59-95.

Deryaoğlu, A., \& Canbaş, A. (2003). Elazığ yöresi Öküzgözü üzümlerinde olgunlaşma sırasında meydana gelen fiziksel ve kimyasal değişmeler. Glda, 28(2), 131140.

Deryaoğlu, A., \& Canbaş, A. (2004). Elazığ yöresi Boğazkere üzümlerinde olgunlaşma sırasında meydana gelen fiziksel ve kimyasal değişmeler. Gıda, 29(1), 105114.

Dıblan, S. (2013). Kalecik Karası üzümlerden (Vitis vinifera L.) üretilen kırmızı üzüm suyunun çeşitli durultma yardımcı maddeleri ile durultulması ve durultmanın üzüm suyu rengi üzerine etkisi. (Yüksek lisans tezi). Ankara Üniversitesi, Fen Bilimleri Enstitüsü, Gıda Mühendisliği Anabilim Dalı, Ankara.

Di Stefano R., \& Cravero, M.C. (1991). Metodi per lo studio dei polifenoli dell'uva. Rivista di Viticoltura e di Enologia, 44(2), 37-45.

Faikoğlu, F. (2014). Adakarası, Papazkarası, Kalecik Karası üzüm çeşitleri kullanılarak üretilen hardalyelerin kalitesinin ve duyusal özelliklerinin araştırılması. (Yüksek lisans tezi). Uludağ Üniversitesi, Fen Bilimleri Enstitüsü, Gıda Mühendisliği Anabilim Dalı, Bursa.

Gülcü, M., Taşeri, L., Boz, Y., \& Dağlığlu, F. (2018). Bazı yerli üzüm çeşitlerinin üzüm suyuna uygunluk derecelerinin belirlenmesi. Yalova Bahçe Kültürleri Merkez Araștırma Enstitüsü Dergisi, 47(Özel sayı:1), 381-388.

Jarvis, C., Barlow, E., Darbyshire, R., Eckard, R., \& Goodwin, I. (2017). Relationship Between Viticultural Climatic İndices and Grape Maturity in Austalia. International Journal of Biometerology, 61(10), 1849-1862.

Karadoğan, B., Keskin, N., Kunter, B., Oğuz, D., \& Kalkan, N.N. (2018). Karaerik (Cimin) Klonlarının Toplam Fenolik ve Antioksidan İçerikleri Bakımından Karşılaştırılması. Bahçe, 47(Özel sayı:1), 117-120.

Kamiloğlu, Ö., \& Üstün, D. (2014). Bazı şaraplık üzüm çeșitlerinin hasat sonrası kalite özellikleri. Türk Tarım ve Doğa Bilimleri Dergisi, 1(3), 361-368.

Karataş, H., Değirmenci, D., \& Ağaoğlu, Y.S. (2010). Kalecik Karası Üzüm Çeşidinde Ürün Dalı İstikametlerinin Üzüm Verim ve Kalite Üzerine Etkileri. Uludağ Üniversitesi, Ziraat Fakültesi Dergisi, 24 (1), 37.46. 
Kayalar, M. (2015). Tokat ilinde farklı yörelerde yetiştirilen Narince üzüm çeşidinden üretilen şarapların bazı kalite özelliklerinin belirlenmesi. (Yüksek lisans tezi). Gazi Osmanpaşa Üniversitesi, Fen Bilimleri Enstitüsü, Gıda Mühendisliği Anabilim Dalı, Tokat.

Keskin, N., Yağcl, A., \& Keskin, S. (2013). Sivas-Gemerek yöresi üzümlerinin bazı kalite özelliklerinin belirlenmesi üzerine bir araștırma. Yüzüncü Yll Üniversitesi Tarım Bilimleri Dergisi, 23, 271-278.

Keskin, N., Çavuşoğlu, Ş., Türkoğlu, N., Özrenk, K., \& Kunter, B. (2018) Siirt ili asma gen kaynakları içerisinde öne çlkan bazı yerli üzüm çeşitlerinin toplam fenolik ve antioksidan içerikleri. Bahçe, 47 (2), 326330.

Kelebek, H. (2009). Değișik bölgelerde yetiștirilen Öküzgözü, Boğazkere ve Kalecik Karası üzümlerinin ve bu üzümlerden elde edilen şarapların fenol bileşikleri profili üzerinde araştırmalar. (Doktora tezi). Çukurova Üniversitesi, Fen Bilimleri Enstitüsü, Gıda Mühendisliği Anabilim Dalı, Adana.

Kök, D., \& Çelik, S. (2003). Bazı Şaraplık Üzüm Çeşitlerinin Etkili Sıcaklık Toplamı Gereksinimlerinin Belirlenmesi ve Bunun Kalite Özellikleri Üzerinde Etkisi. Trakya Üniversitesi Bilimsel Araştırmalar Dergisi 4(1), 23-27.

Kunter, B., Cantürk, S., \& Keskin, N. (2013). Üzüm tanesinin histokimyasal yapısı. Iğdır Üniversitesi, Fen Bilimleri Enstitüsü Dergisi, 3(2), 17-24.

Moscowitz, A.H., \& Hrazidna, G. (1981). Vacuolar contents of fruit subepidermal cells from vitis species. Plant Physiol, 68, 686-692.

Muhammad, A.G. (2014). Sauvignon blanc, Merlot ve Kalecik Karası üzümlerinden malolaktik fermantasyon ile elde edilen şarapların fizikokimyasal ve duyusal karakterlerinin belirlenmesi üzerine bir araștırma. (Doktora tezi). Dumlupınar Üniversitesi, Fen Bilimleri Enstitüsü, Biyoloji Anabilim Dalı, Kütahya.

Otağ, M.R. (2015). Denizli Çal yöresinde yetişen bazı üzüm çeşitlerinin farklı olgunlaşma evreleri ve kurutulması sonrasında bazı özellikleri ile resveratrol içeriğinin belirlenmesi. (Doktora tezi), Pamukkale Üniversitesi, Fen Bilimleri Enstitüsü, Gıda Mühendisliği Anabilim Dalı, Denizli.

Ough, C. S., \& Amerine, M. A. (1988). Methods for analysis of musts and wines, pp. 377, John Wiley New York.

Özdemir, G., \& Sessiz, A., (2018). Öküzgözü boğazkere ve șire üzüm çeșitlerine ait tanelerin farklı olgunluk dönemlerinde meydana gelen fiziksel ve kimyasal değişimlerin belirlenmesi. BAHÇE 47, 243-248.
Pirie, A.J.G., \& Mullins, M.G. (1980). Concentration of phenolics in the skin of grape berries during fruit development and ripening. American Journal of Enology and Viticulture, 31(1), 34-36.

Polat, A. (2016). Şanlıurfa ilinde yetiştiriciliği yapılan üzüm çeşitlerinin bazı fitokimyasal profillerinin belirlenmesi. (Doktora tezi). Harran Üniversitesi, Fen Bilimleri Enstitüsü, Bahçe Bitkileri Anabilim Dalı, Urfa

Ribéreau-Gayon, P., Glories Y., Maujean, A., \& Dubourdieau, U. (2000). Handbook of Enology, Volume 2: The chemistry of wine and stabilization and treatments. John Wiley and Sons Ltd., 441 p.

Selli, S., Cabaroğlu, T., \& Canbaș, A. (2001). Kalecik Karası şırasındaki serbest aroma maddelerinin tayininde iki farklı ekstraksiyon yönteminin kıyaslanması. Gıda, 26(6), 443-448.

Serraino, I., Dugo, L., Dugo, P., Mondello, L., Mazzon, E., Dugo, G., Caputi, A.B., \& Cuzzocrea, S. (2003). Protective effects of cyanidin-3-,0-glucoside from blackberry extract against peroxynitrit-ınduced endothelial dysfunction and vascular failnure. Life Sciences, 73, 1097-1114.

Shadidi, F., \& Naczk M. (1995). Food phenols: source, Chemistry, effects and applications. Technomic Publishing Company (USA). pp. 331.

Söylemezoğlu, G. (2003). Üzümde fenolik bileșikler. Gıda, 28(3), 277-285.

Şan, H.F. (2016). Ülkemizde üretilen önemli yerli ve yabancı şaraplık üzüm çeşitlerinin şeker ve organik asit içeriklerinin belirlenmesi. (Yüksek lisans tezi). Çukurova Üniversitesi, Fen Bilimleri Enstitüsü, Gıda Mühendisliği Anabilim Dalı, Adana.

Șen, A. (2008). Kazova (Tokat) ekolojisinde yetiștirilen bazı üzüm çeşitlerinde etkili sıcaklık toplamı ve optimum hasat zamanlarının belirlenmesi. (Yüksek lisans tezi),Gaziosmanpaşa Üniversitesi, Fen Bilimleri Enstitüsü, Tokat.

Tahmaz, H. (2009). Kalecik Karası üzüm çeşidi klon adaylarının gelişme, verim ve ürün kalitesi yönüyle değerlendirilmesi.(Yüksek lisans tezi). Ankara Üniversitesi, Fen Bilimleri Enstitüsü, Ankara.

Tomera, J. (1999). Current knowledge of the health benefits and disadvantages of wine consumption. Trends in Food and Science, 10, 129-138.

Toprak, F.E. (2011). Ankara ve Nevșehir illerinde yetiştirilen Kalecik Karası üzüm çeşidinin fitokimyasal özellikleri üzerine araştırmalar. (Yüksek lisans tezi). Ankara Üniversitesi, Fen Bilimleri Enstitüsü, Bahçe Bitkileri Anabilim Dalı, Ankara 
Uluocak, E. (2010). Kazova (Tokat) yöresinde yetiştirilen bazı şaraplık üzüm çeşitlerinde olgunlaşma sırasında meydana gelen fiziksel ve kimyasal değişmeler.(Yüksek lisans tezi). Gaziosmanpaşa Üniversitesi. Fen Bilimleri Enstitüsü, Tokat.

Uzun, T., Bahar, E., Cangi, R. \& Bayram, M. (2019a). Effects on chemical composition and phenolic compounds of Mustand wines produced with remove approximately 45 of leaves of narince grapes grown in three territories. Ejons-International Refereed Indexed Journal on Mathematic, Engineering And Natural Sciences, 3(10), 91-106.

Uzun, T., Cangi, R. \& Bayram, M. (2019b). Effects of cluster thinning treatments on chemical composition and phenolic compounds of grape juice and wines of Narince (V. vinifera L.) grape cultivar. Fresenius Environmental Bulletin, 28(12/A), 9669-9678.

Ünal, M.Ü., \& Şener, A. (2016). Correlation between browning degree and composition of important Turkish white wine grape warieties. Turkish Journal of Agriculture and Foresty, 40(1), 62-67.

Van Leeuwen, C., Garnier, C., Agut, C., Baculat, B., Barbeau, G., Besnard, E., Bois, B., Boursiquot, J.M., Chuine, I., Dessup, T., Dufourcq, T., Garciacortazar, I., Marguerit, E., Monamy, C., Koundouras, S., Payan, J.C., Parker, A., Renouf, V., Rodriguez-Lovelle, B., Roby, J.P., Tonietto, J., \& Trambouze, W. (2008). Heat Requirements for Grapevine Varieties Essential Information to Adapt Plant Material in a
Changing Climate. VIIth International Terroir Congress.

Velioğlu, Y.S., Mazza, G., Gao, L. \& Oomah, B.D. (1998). Antioxidant activity and total phenolics in selected fruits, vegetables, and grain products. Journal of Agricultural and Food Chemistry, 46(10), 41134117.

Waterhouse, A.L. (2002). Determination of total phenolics. Current Protocols in Food Analytical Chemistry I1.1.1-I1.1.8 John Wiley \& Sons, Inc.

Winkler, A.J., Cook, J.A., Kliewer, W.M., \& Lider, L.A. (1974). General viticulture. University of California Press. Berkeley. California. 710 p.

Yabacı Karoğlan, S.N. (2015). Yöre özelliklerinin Bornova Misketi üzümü ve şarabının kalite parametreleri, aroma ve fenol bileşikleri üzerine etkileri. (Doktora tezi). Çukurova Üniversitesi, Fen Bilimleri Enstitüsü, Bahçe Bitkileri Anabilim Dalı, Adana.

Yüksel, D. (2014).Bazı şaraplık ve sofralık üzüm çeşitlerinde toplam fenolik madde, toplam antosiyanin ve antioksidan kapasite miktarlarının belirlenmesi üzerine bir araştırma. (Yüksek lisans tezi). Ankara Üniversitesi, Fen Bilimleri Enstitüsü, Bahçe Bitkileri Anabilim Dalı, Ankara.

Zhishen, J., Mengcheng, T., \& Jianming, W. (1999). The determination of flavonoid contents in mulberry and their scavenging effects on superoxide radicals. Food Chemistry, 64, 555-55. 